\title{
Piotr Pieczonka
}

adwokat, Gdańsk

pieczonka@kpnp.pl

ORCID: https://orcid.org//0000-0001-5029-0649

\section{Glosa do postanowienia Sądu Najwyższego $z$ dnia 16 listopada 2018 r., I CSK 646/17}

http://dx.doi.org/10.12775/SIT.2019.030

W komentowanym postanowieniu Sąd Najwyższy powrócił do istotnego dla funkcjonowania wspólnot mieszkaniowych, lecz budzącego w praktyce szereg wątpliwości, problemu skutków prawnych przebudowy samodzielnego lokalu i przyłączenia do niego części nieruchomości wspólnej. W orzeczeniu tym Sąd Najwyższy uznał, że do wpisu w księdze wieczystej połączenia lokalu stanowiącego odrębną nieruchomość w rozumieniu art. 2 ust. 2 Ustawy $z$ dnia 24 czerwca 1994 r. o własności lokali ${ }^{1}$ (dalej: u.w.l.) z częścią nieruchomości wspólnej w związku $z$ dokonaną nadbudową lub przebudową i utratą przez część nieruchomości wspólnej takiego charakteru nie jest konieczne ustanowienie odrębnej własności nowo powstałego lokalu w miejsce dotychczasowego prawa przysługującego właścicielowi nieruchomości lokalowej. Jednocześnie potwierdził, że konieczne jest ponowne określenie wysokości udziałów w nieruchomości wspólnej, co jest następstwem zmiany powierzchni lokalu i powierzchni nieruchomości wspólnej.

${ }^{1}$ Tekst jedn.: Dz.U. z 2018 r., poz. 716 ze zm. 
Powyższe orzeczenie zapadło w następującym stanie faktycznym właściciele lokalu mieszkalnego za zgodą wspólnoty przebudowali należący do nich samodzielny lokal tak, że objął on część nieruchomości wspólnej. Następnie właściciele tego lokalu oraz wspólnota mieszkaniowa (reprezentowana przez zarząd wspólnoty działający na podstawie pełnomocnictwa udzielonego mu uchwałą wspólnoty), w którym ten lokal się znajduje, zawarli w formie aktu notarialnego umowę, na mocy której dokonali zmiany umowy ustanowienia odrębnej własności lokalu mieszkalnego przez przyłączenie do tego lokalu części nieruchomości wspólnej i sprzedaż części dotychczasowej nieruchomości wspólnej. W związku z zawarciem umowy strony wniosły m.in. o sprostowanie oznaczenia lokalu w księdze wieczystej, wpis prawa własności i zmiany w działach I-Sp ksiąg wieczystych.

Na wstępie należy zauważyć, że Sąd Najwyższy już wcześniej zajmował się zagadnieniem wyodrębnienia $z$ nieruchomości wspólnej jej części i włączenia tak wyodrębnionej funkcjonalnie części nieruchomości wspólnej do nieruchomości lokalowej, przez co nieruchomość lokalowa zyskała nową konfigurację i powierzchnię 2 . W konsekwencji wobec zmiany konfiguracji i powierzchni samodzielnego lokalu pojawiło się pytanie o tożsamość przedmiotu prawa odrębnej własności lokalu sprzed przyłączenia części nieruchomości wspólnej i po tym zdarzeniu, a zatem wątpliwość, czy konieczne jest ponowne ustanowienie odrębnej własności lokalu ${ }^{3}$. W uchwale $z$ dnia 25 listopada 2011 r. $^{4}$ przyjęto, że w razie dokonania przebudowy kosztem nieruchomości wspólnej musi dojść do przeniesienia na właściciela lokalu udziału w nieruchomości wspólnej, odpowiadającego powierzchni wyłączonej z nieruchomości wspólnej w związku z jej przebudową, ustanowienia odrębnej własności lokalu powstałego w następstwie przebudowy na rzecz

\footnotetext{
2 Uchwała Sądu Najwyższego z dnia 25 listopada 2011 r., III CZP 65/11, OSNC 2012/6/68.

${ }^{3}$ M. Marcysiak, Glosa do uchwały SN z dnia 25 listopada 2011 r., III CZP 65/11, Lex/el. 2012.

${ }^{4}$ Uchwała Sądu Najwyższego z dnia 25 listopada 2011 r., III CZP 65/11, OSNC 2012/6/68.
} 
właściciela, który przyłączył do nieruchomości lokalowej element części wspólnej, w miejsce dotychczas przysługującego mu prawa odrębnej własności oraz do zmiany wysokości dotychczasowych udziałów.

We wcześniejszym orzecznictwie Sąd Najwyższy dopuszczał jednak usunięcie niezgodności między stanem prawnym wynikającym z umowy ustanowienia odrębnej własności lokalu a stanem faktycznym, powstałym na skutek jego rozbudowy, w drodze zmiany umowy o ustanowieniu odrębnej własności lokalu ${ }^{5}$ albo - jeżeli zmiana następowała kosztem innego lokalu - przez przeniesienie na rzecz właściciela fizycznie oznaczonej części innego lokalu, pod warunkiem zachowania przez oba lokale cechy samodzielności ${ }^{6}$. W odniesieniu natomiast do przyłączenia do lokalu pomieszczeń przynależnych już po wyodrębnieniu własności lokalu wskazywano, że może to nastąpić przez zniesienie w tym zakresie współwłasności nieruchomości wspólnej ${ }^{7}$.

Jak słusznie zauważył Sąd Najwyższy w komentowanym postanowieniu $\mathrm{z}$ dnia 16 listopada 2018 r., konstrukcja odrębnej własności lokali zakłada współistnienie prawa własności lokalu, stanowiącego odrębną nieruchomość (art. 2 ust. 1 u.w.l. w związku z art. 46 k.c.) oraz współwłasności nieruchomości wspólnej, na którą składają się grunt i części budynku oraz urządzenia, które nie służą wyłącznie do użytku właścicieli lokali. Współwłasność ta ma charakter przymusowy, gdyż powstaje $z$ mocy prawa, a jej zniesienie nie może nastąpić, dopóki trwa odrębna własność lokali, natomiast udział $\mathrm{w}$ nieruchomości wspólnej jest prawem związanym $\mathrm{z}$ własnością lokalu (art. 3 ust. 1 u.w.1.).

W orzecznictwie i literaturze przedmiotu przyjmuje się, że zakaz zniesienia współwłasności nieruchomości wspólnej dotyczy tylko tych jej elementów, które są nieodzowne do korzystania z lokali,

${ }^{5}$ Uchwała Sądu Najwyższego z dnia 3 kwietnia 1986 r., III CZP 5/86.

${ }^{6}$ Postanowienie Sądu Najwyższego z dnia 10 kwietnia 1989 r., III CRN 66/89, OSNC 1991, nr 1, poz. 14.

7 Por. uchwałę Sądu Najwyższego z dnia 3 października 2003 r., III CZP 65/03, uchwałę Sądu Najwyższego z dnia 15 listopada 2018 r., III CZP 52/18, OSNC 2019/9/89. 
tworząc składniki konieczne nieruchomości wspólnej, a w pozostałym zakresie możliwe są zmiany granic części wspólnych i poszczególnych lokali ${ }^{8}$. Wynika to $z$ faktu, że elementy składające się na nieruchomość wspólną mogą mieć zróżnicowany charakter, niektóre z nich są bowiem konieczne do korzystania $z$ lokali (np. klatka schodowa, ściany zewnętrzne, dach, wejście do budynku, korytarze), a inne elementy mogą jedynie wpływać na jakość korzystania z lokali, lecz nie są do tego niezbędne (np. strychy, komórki, garaże).

Należy podzielić pogląd, że kategoria części wspólnej nieruchomości ma charakter funkcjonalny i zarazem jest na tyle elastyczna, że status prawny danego elementu nieruchomości budynkowej uzależniony jest od okoliczności konkretnego przypadku ${ }^{9}$.

Zgodnie $z$ art. 22 ust. 3 pkt 5 u.w.l. do czynności przekraczających zakres zwykłego zarządu zalicza się również udzielenie zgody na nadbudowę lub przebudowę nieruchomości wspólnej, na ustanowienie odrębnej własności lokalu powstałego w następstwie nadbudowy lub przebudowy i rozporządzenie tym lokalem oraz na zmianę wysokości udziałów w następstwie powstania odrębnej własności lokalu nadbudowanego lub przebudowanego. Zatem na tej podstawie dopuszczalna jest tego rodzaju przebudowa nieruchomości wspólnej, która samodzielnie lub w powiązaniu $\mathrm{z}$ nadbudową doprowadzi częściowo albo w całości, kosztem powierzchni nieruchomości wspólnej, do powstania samodzielnego lokalu mieszkalnego i umożliwi wyodrębnienie oraz rozporządzenie nowym lokalem, przy czym zmianie tej musi towarzyszyć zmiana udziałów w nieruchomości wspólnej.

${ }^{8}$ D. Kurek, Ustawa o własności lokali. Komentarz, wyd. 13, Legalis 2019; H. Izdebski (red.), Ustawa o własności lokali. Komentarz, WKP, Warszaw 2019, uchwała Sądu Najwyższego z dnia 3 października 2003 r., III CZP 65/03, OSNC 2004, nr 12, poz. 189, uchwała z dnia 14 lipca 2005 r., III CZP 43/05, OSNC 2006, nr 6, poz. 98, postanowienie Sądu Najwyższego z dnia 27 sierpnia 2015 r., III CSK 383/14, Lex nr 1844087, wyrok Sądu Najwyższego z dnia 31 marca 2016 r., IV CNP 33/15, Lex nr 2037902, wyrok Sądu Apelacyjnego w Warszawie z dnia 25 maja 2016, VI ACa 605/15, Lex nr 2076729.

${ }^{9}$ K. Osajda (red.), Ustawa o własności lokali. Komentarz, wyd. 7, Legalis 2019. 
Sąd Najwyższy w postanowieniu z dnia 16 listopada 2018 r. uznał, że przebudowa substancji budynku nie musi jednak mieć na celu powstania nowego odrębnego lokalu, może także zmierzać - samodzielnie lub w powiązaniu $z$ nadbudową - jedynie do zwiększenia powierzchni wyodrębnionego już lokalu lub lokali o część nieruchomości wspólnej zaadaptowaną, względnie nadbudowaną, w tym celu przez właściciela lokalu, z którym część ta jest funkcjonalnie związana, a po dokonaniu koniecznych zmian - będzie tworzyć architektoniczną całość. Dopuszczalność tego rodzaju korekt została przesądzona w orzecznictwie Sądu Najwyższego, w którym przyjęto, że analogiczne zastosowanie ma w tym przypadku art. 22 ust. 3 pkt 5 u.w.1. ${ }^{10}$ Słusznie zatem w komentowanym postanowieniu Sąd Najwyższy uznał, że nic nie stoi na przeszkodzie, by dokonać tego rodzaju modyfikacji w konfiguracji nieruchomości wspólnej i wyodrębnić lokal, z dwoma jednak zastrzeżeniami:

- lokal, któremu mają służyć te zmiany, musi zachować przymiot samodzielności;

- zmiany te nie mogą ingerować w samodzielność innych lokali, bezpośrednio nimi niedotkniętych.

Zagadnienie prawne, $\mathrm{z}$ jakim mamy do czynienia $\mathrm{w}$ przypadku powiększenia wyodrębnionego lokalu kosztem nieruchomości wspólnej, sprowadza się do ustalenia, na podstawie jakiej czynności dochodzi do wyjścia ze stanu współwłasności zaadaptowanej na potrzeby lokalu części nieruchomości wspólnej i rozporządzenia tą częścią na rzecz właściciela lokalu. Dokonanie zmian architektonicznych w obrębie nieruchomości wspólnej nie rzutuje na status prawny tych elementów jako objętych współwłasnością właścicieli lokali i nie wpływa na granice nieruchomości lokalowej ${ }^{11}$. Jednocześnie w uchwale tej Sąd Najwyższy stanął na stanowisku, że jeżeli mieszkanie powiększyło się na skutek przebudowy sąsiadującego

${ }^{10}$ Por. uchwałę Sądu Najwyższego z dnia 25 listopada 2011 r., III CZP 65/11, OSNC 2012, nr 6, poz. 68 oraz uchwałę Sądu Najwyższego z dnia 3 kwietnia 1986 r., III CZP 5/86, OSNCP 1987, nr 2-3, poz. 29.

${ }^{11}$ Uchwała Sądu Najwyższego z dnia 25 listopada 2011 r., III CZP 65/11, OSNC 2012/6/68. 
z nim strychu, sama zmiana księgi wieczystej nie wystarczy, lecz trzeba na nowo wyodrębnić własność lokalu. W uzasadnieniu swojego stanowiska zaprezentowanego w tej uchwale, Sąd Najwyższy popadł w pewną sprzeczność, stwierdzając, że: „Samodzielny lokal mieszkalny, będący przedmiotem odrębnej własności lokalu, może podlegać przebudowom prowadzonym w granicach wyznaczonych przez ściany, które wyodrębniają lokal z przestrzeni budynku i decydują o jego powierzchni i konfiguracji. Dopuszczalność takiej przebudowy lokalu może być uzależniona od uzyskania stosownych zezwoleń na drodze administracyjnej (pozwolenie na budowę lub zgłoszenie), ale jej wykonanie prowadzi co najwyżej do zmiany konfiguracji samodzielnego lokalu mieszkalnego jako przedmiotu odrębnej własności, co - na wniosek właściciela - powinno znaleźć odzwierciedlenie w księdze wieczystej prowadzonej dla nieruchomości lokalowej. Takie zmiany nie wiążą się z powstaniem przedmiotu prawa o innych istotnych właściwościach ani nie wpływają na zmianę powierzchni innego samodzielnego lokalu lub nieruchomości wspólnej”. Wynika z tego bowiem, że z jednej strony uznał, iż przyłączenie fragmentu nieruchomości wspólnej do wyodrębnionego lokalu nie powoduje powstania prawa o innych istotnych cechach, a jednocześnie przyjął, że konieczne jest wygaszenie dotychczasowego prawa i wyodrębnienie na nowo własności lokalu. Sąd Najwyższy w uchwale z 25 listopada 2011 r. nie wyjaśnił jednak, jakie zdarzenie prawne skutkuje wygaśnięciem dotychczasowego prawa odrębnej własności lokalu, choć stwierdził, że nie powoduje takiego skutku sama przebudowa samodzielnego lokalu mieszkalnego oraz nieruchomości wspólnej, przebudowa jest bowiem zdarzeniem faktycznym, które może być odwrócone.

W uzasadnieniu postanowienia z 16 listopada 2019 r. Sąd Najwyższy natomiast zajął odmienne stanowisko: stwierdził, że nie można mówić o jednym określonym wzorcu umowy, która w razie adaptacji części nieruchomości wspólnej i dokonania nadbudowy umożliwiałaby osiągnięcie skutku w postaci zmiany kształtu i powierzchni nieruchomości lokalowej. Zawsze jednak rezultatem czynności prawnej odnoszącej się do włączenia części nieruchomości wspólnej do wyodrębnionego lokalu będzie powstanie nieruchomości lokalowej o zmodyfikowanej powierzchni i konfiguracji 
oraz zmiana wysokości udziałów w nieruchomości wspólnej ${ }^{12}$. Sąd Najwyższy opowiedział się przy tym za uznaniem, że nie jest konieczne ustanowienie odrębnej własności nowo powstałego lokalu $\mathrm{w}$ miejsce dotychczasowego prawa przysługującego właścicielowi nieruchomości lokalowej. Stwierdził równocześnie, że część budynku nie jest odrębną rzeczą, lecz nie stoi to jednak na przeszkodzie, by zawrzeć umowę obejmującą taką część, mającą wywołać skutek rzeczowy, jeżeli jurydyczne wyodrębnienie tej części z całości jest możliwe. Skutek rzeczowy czynności zostaje wtedy odroczony do chwili prawnego wyodrębnienia zbywanej części, co następuje $\mathrm{z}$ chwilą dokonania wpisu $\mathrm{w}$ księdze wieczystej ${ }^{13}$. Jak wyjaśnił, sytuacja ta jest w pewnym stopniu zbliżona do tej, w której przedmiotem sprzedaży jest część nieruchomości gruntowej, uzyskująca status samodzielnej rzeczy - nieruchomości gruntowej - $z$ chwilą jej odłączenia i ujawnienia w księdze wieczystej. O ile jednak podział nieruchomości gruntowych nie jest obwarowany szczególnymi rygorami ze względu na ich $z$ natury podzielny charakter, o tyle dopuszczalność wyodrębnienia części budynku wymaga szczególnej podstawy prawnej. W przypadku nieruchomości wspólnej podstawa ta wynika $\mathrm{z}$ ustawy o własności lokali, z zastrzeżeniem, że lokal, do którego przyłączono elementy wydzielone $z$ nieruchomości wspólnej, musi odpowiadać wymaganiu samodzielności.

Sąd Najwyższy w tym wypadku opowiedział się za uznaniem, że w takiej sytuacji dochodzi do przyłączenia do dotychczasowej nieruchomości lokalowej części nieruchomości wspólnej (nieruchomości gruntowej, której częścią składową jest wzniesiony na niej budynek), a efektem tego zdarzenia prawnego jest powiększenie dotychczasowej nieruchomości lokalowej kosztem nieruchomości wspólnej (oraz jednoczesna zmiana udziałów w nieruchomości wspólnej) ${ }^{14}$.

12 Por. wyrok Sądu Najwyższego z dnia 14 czerwca 2017 r., IV CSK 478/16, Lex nr 2334888.

13 Zob. wyrok Sądu Najwyższego z dnia 6 listopada 1964 r., I CR 235/64, OSNCP 1965, nr 7-8, poz. 29, wyrok Sądu Najwyższego z dnia 25 lipca 2001 r., I CKN 372/00, Lex nr 332887, wyrok Sądu Najwyższego z dnia 17 listopada 2005 r., IV CSK 5/05, Lex nr 186707, postanowienie Sądu Najwyższego z dnia 10 kwietnia 1989 r., III CRN 66/89.

14 M. Marcysiak, op.cit. 
Z perspektywy nieruchomości lokalowej, do której następuje przyłączenie zaadaptowanej części nieruchomości wspólnej, rozporządzenie prawem do oznaczonej części nieruchomości wspólnej na rzecz właściciela lokalu, który dokonał jej adaptacji, należy traktować jako szczególny przypadek połączenia nieruchomości uregulowany w art. 21 Ustawy z 24 czerwca 1994 r. o księgach wieczystych i hipotece (t.j. Dz.U. 2019, poz. 737). Skutkiem tej czynności jest równocześnie częściowe ustanie wspólności nieruchomości wspólnej w zakresie odpowiadającym elementom włączonym do nieruchomości lokalowej. W analizowanym orzeczeniu Sąd Najwyższy zauważył, jakie problemy powoduje podejście zaprezentowane $\mathrm{w}$ uchwale $z$ dnia 25 listopada 2011 r. ${ }^{15}$, zarazem akcentując, że stanowisko przedstawione w postanowieniu z 16 listopada 2018 r. pozwala uniknąć niektórych komplikacji, które wiążą się z koniecznością ustanowienia w miejsce mającego wygasnąć prawa odrębnej własności lokalu odrębnej własności lokalu nowo powstałego. Trudności te dotyczą m.in. skonkretyzowania podstaw ustania dotychczasowej odrębnej własności lokalu, skoro nie prowadzi do niej dokonanie odwracalnych zmian architektonicznych w substancji lokalu, oraz - przede wszystkim - konsekwencji tego zdarzenia dla bytu praw rzeczowych obciążających dotychczasowy lokal. Nie jest w tym przypadku także potrzebne uprzednie i odrębne rozporządzenie udziałem w nieruchomości wspólnej, mające warunkować nabycie przez właściciela nieruchomości lokalowej tytułu do zaadaptowanej przezeń części nieruchomości wspólnej, co rozwiązuje dyskusyjny w świetle art. 3 ust. 1 u.w.l. problem dopuszczalności takiego samodzielnego rozporządzenia.

Podsumowując analizowane orzeczenie Sądu Najwyższego, należy uznać przyjęty w nim kierunek interpretacji za właściwy. Sąd Najwyższy w uzasadnieniu postanowienia, tak samo jak w uchwale $\mathrm{z}$ dnia 25 listopada $2011 \mathrm{r}^{16}$ trafnie uznał, że przebudowanie samodzielnego lokalu mieszkalnego przez przyłączenie do niego części nieruchomości wspólnej może prowadzić do powstania nowej nieruchomości lokalowej oraz że w skutek tych czynności faktycznych

15 Uchwała Sądu Najwyższego z dnia 25 listopada 2011 r., III CZP 65/11.

${ }^{16}$ Uchwała Sądu Najwyższego, op. cit. 
(przebudowa) nie dochodzi do zmiany prawa własności. Potrzebna jest do tego dodatkowa czynność prawa, podjęta w formie aktu notarialnego, na mocy której nie następuje ponowne wyodrębnienie lokalu, a jedynie przyłączenie do niego części nieruchomości wspólnej oraz jednoczesna zmiana dotychczasowych udziałów w nieruchomości wspólnej.

\section{STRESZCZENIE}

Glosa do postanowienia Sądu Najwyższego z dnia 16 listopada 2018 r., I CSK 646/17

Glosa dotyczy problematyki skutków prawnych przebudowy samodzielnego lokalu i przyłączenia do niego części nieruchomości wspólnej. Postanowienie Sądu Najwyższego daje wskazówki, jak należy dokonać czynności polegającej na przyłączeniu fragmentu nieruchomości wspólnej do samodzielnego lokalu, jakie elementy taka czynność prawna musi obejmować oraz kiedy jest ona dopuszczalna i może stanowić podstawę do ujawnienia zmiany w księdze wieczystej.

Słowa kluczowe: nieruchomość wspólna; wyodrębnienie; przyłączenie; samodzielny lokal; czynność przekraczająca zakres zwykłego zarządu; współwłasność

\section{SUMMARY}

A gloss to the decision of the Supreme Court of November 16, 2018, I CSK 646/17

The gloss concerns the issue of the legal consequences of the reconstruction of an independent premises and the attachment of part of the common property to it. The decision of the Supreme Court gives instructions on how to perform the act of connecting a part of the common property to an independent premises, what elements of such a legal act must include and when it is admissible and may constitute a basis for disclosing the change in the land and mortgage register.

Keywords: common property; separation, connection; independent premises; activity exceeding the scope of ordinary management; co-ownership 


\section{BIBLIOGRAFIA}

Marcysiak M., Glosa do uchwały $\mathrm{SN}$ z dnia 25 listopada 2011 r., III CZP 65/11, Lex/el. 2012.

Kurek D., Ustawa o własności lokali. Komentarz, wyd. 13, Legalis 2019. Izdebski H. (red.), Ustawa o własności lokali. Komentarz, Warszawa 2019. Osajda K. (red.), Ustawa o własności lokali. Komentarz, wyd. 7, Legalis 2019. 